\title{
Social capacities for drought risk management in Switzerland
}

\section{S. Kruse and I. Seidl}

Swiss Federal Institute for Forest, Snow and Landscape Research, Economics and Social Sciences, Zürcherstr. 111, 8903 Birmensdorf, Switzerland

Correspondence to: S. Kruse (sylvia.kruse@wsl.ch)

Received: 22 January 2013 - Published in Nat. Hazards Earth Syst. Sci. Discuss.: 17 April 2013

Revised: 7 October 2013 - Accepted: 1 November 2013 - Published: 23 December 2013

\begin{abstract}
This paper analyses the social capacities for drought risk management from the perspective of national and regional water users and policy- and decision-makers in Switzerland. The analysis follows five dimensions of social capacities as prerequisites for drought risk management. Regarding information and knowledge (1), basic data is available, however not assembled for an integrated drought information system. As for technology and infrastructure (2), limited proactive capacities are available with the exception of a few of the drought-prone regions; in emergency response to drought however, provisional capacities are put together. Regarding organisation and management (3) most regions have enough personnel and effective cooperation in the case of acute and sporadic drought; long-term strategies though are largely missing. Economic resources (4) are sufficient if droughts remain rare. Finally, institutions and policies (5) are not sufficient for proactive drought risk management, but have been suitable in the drought of 2003. Starting points for building social capacities are first, to draw on the extensive experiences with the management of other natural hazards, second to build an integrated drought information system, including social and economic impacts, and third to improve the institutional framework through consistent regulations and coordination for proactive drought risk management.
\end{abstract}

\section{Introduction}

Droughts are complex hydro-climatic, environmental and socio-economic phenomena and mostly related to the decrease in the amount of precipitation over an extended period of time, inflicting damage to an activity, group or environment (Mishra and Singh, 2010; Kallis, 2008; Tate and Gustard, 2000; Van Lanen and Peters, 2000). The general climatic conditions within a particular region, as well as local characteristics such as soil properties, snow pack, altitude and basin size, influence the spatial occurrence, duration and severity of droughts. Additionally, water usage and water needs differ among users, and external factors influence the vulnerability of water user groups to drought events (Kallis, 2008). Droughts and low flow situations can result in a slow onset hazard that develops over time. Its impacts are diffuse, indirect and spread slowly, in contrast to other rapid onset natural hazards, such as floods, earthquakes and landslides. Droughts affect certain areas in Europe almost every year, mostly in the Mediterranean (e.g. Spain, France, Italy) and central and eastern Europe (e.g. Hungary, Bulgaria, Russia), hence the impacts are highly place- and user-group specific (Kallis, 2008; Bradford, 2000).

In Switzerland, known as the water tower of Europe (EEA, 2009), droughts have been rare in the 20th century. Droughts only occurred in the years 1947, 1949, 1976, and 2003, although more frequently in earlier centuries (Pfister and Rutishauser, 2000). Thus, unlike other European countries, e.g. Spain, France and Italy, Switzerland has not established a national approach of integrated drought risk management including all phases from proactive mitigation, preparedness and early recognition, to reactive impact assessment, response and recovery (Vogt and Somma, 2000). Yet, Switzerland has some regions which have suffered drought effects regularly for centuries and have established mitigation systems, e.g. the centuries-old irrigation systems (Suones) in the Valais (Rodewald and Knoepfel, 2011) or the effective fire prevention management system in the Ticino (Pezzatti et al., 2013).

In Switzerland, similar to other affected countries in Europe, the 2003 drought event stands out as a "climatic surprise" (Beniston and Stephenson, 2004). Extremely high temperatures and low precipitation resulted in drought and 
heat waves that affected many regions in Switzerland that had not experienced droughts for a long time (Beniston and Stephenson, 2004). The 2003 drought event had severe impacts on both the environment (e.g. significantly lower discharge in many rivers; rapid mass losses of mountain glaciers; unusually high amounts of slope instability events) and on socio-economic systems (heat-related health problems and mortality, economic losses for the agricultural and the energy sector) (BUWAL et al., 2004; ProClim, 2005; Fuhrer et al., 2006; Beniston, 2007). Public authorities, politicians and the different water users, such as farmers, shipping operators, hydropower companies, health services and forest fire services, were surprised by the severity of the drought event and by its impacts.

As a consequence, since 2003 drought risks have been on the agenda of both national and regional policyand decision-makers as well as private water users in Switzerland. On the national level for example, drought has been issued as one of the biggest challenges for climate adaptation in the national adaptation strategy (BAFU, 2012a) and a parliamentarian initiative was launched in 2010 to strengthen drought risk management (BAFU, 2012b). Also many public and private actors and water users (e.g. farmers, municipalities, water and energy supplier) have become concerned about drought risks and they are currently preparing strategies on how to deal with future drought events, for example the federal office for agriculture in its climate strategy (BLW, 2011) and the Canton of Fribourg, which commissioned a study on seasonal water scarcity and irrigation needs in the agriculture sector (Collet and von Niederhäusern, 2008; also cf. Karrer, 2012). However, establishing effective drought risk management, understood as a process to avoid, lessen or transfer the adverse effects of drought hazards in Switzerland, is a long-term process that involves a set of social capacities, i.e. the abilities, skills and internal resources to successfully anticipate and respond to hazard events and their impacts (Kuhlicke et al., 2011).

The aim of the paper is to provide a structured analysis of the social capacities for drought risk management in Switzerland from the perspective of water users and policyand decision-makers on the national and cantonal level. With this analysis we aim at identifying starting points for building social capacities for drought risk management. The research question guiding the investigation presented here is: What social capacities exist so far for drought risk management in Switzerland from the perspective of water users and policyand decision-makers?

The analysis is based on data from two research projects: "Early recognition of critical drought and low-flow conditions in Switzerland" (Funding: Swiss National Science Foundation) and "Fostering European Drought Research and Science-Policy Interfacing" (Funding: EU FP7). Data was collected in standardised surveys, in expert interviews and in stakeholder workshops with policy- and decision-makers and water users.
The paper is structured as follows: first we sketch a conceptual framework for the investigation of social capacities for drought risk management (Sect. 2) which we apply to the analysis and presentation of the results. After describing the methods used for the study of drought risk management in Switzerland (Sect. 3) we present the results differentiating between social capacities for proactive and for reactive drought risk management (Sect. 4). In Sect. 5 we discuss the social capacities for drought risk management in Switzerland, focussing on the implications for capacity building, the limitations and the transferability of results, and draw conclusions in Sect. 6.

\section{Conceptual framework: investigating social capacities for drought risk management}

According to the United Nations Office for Disaster Risk Reduction (UN-ISDR), drought risk management is the concept and practice to avoid, lessen or transfer the adverse effects of drought hazards and the potential impacts of disasters through activities and measures for mitigation, preparedness, response and recovery (UN-ISDR, 2009). Scholars conceive drought risk management as a continuous process following the disaster management cycle with proactive strategic measures in preparation for future drought events and with reactive emergency measures in the onset of a drought (cf. Fig. 1; Rossi, 2000; Wilhite et al., 2000; Kampragou et al., 2011). Following the disaster management cycle, proactive drought risk management includes implementing mitigation activities, increasing preparedness for future drought events, and establishing and improving an early recognition system for drought events. Reactive drought risk management involves conducting an impact assessment during and after a drought event, realising response measures in the affected areas, and accomplish recovery from drought damages. The phases of the drought risk management cycle do not necessarily occur in the linear way the cycle suggests. For example, early recognition of a drought event and impact assessment may merge if an integrated drought information and warning system exists; the implementation of measures for recovery from drought events (e.g. artificial ground water recharge; reforestation of an area affected by forest fire) may need years, during which mitigation and preparedness (e.g. investment in water infrastructure; establishing forest fire emergency services) is strengthened simultaneously.

The presence of social capacities is a necessary precondition for social actors to realise proactive and reactive drought risk management measures. At the same time, drought risk management measures that have been put into practice enhance the social capacities of the social system under investigation, e.g. drought risk management in Switzerland. In natural hazard management, social capacities refer to the abilities, skills and internal resources of an individual, group or organisation to successfully anticipate and respond to external 
stressors, i.e. the natural hazard events and their impacts (Kuhlicke et al., 2011; Höppner et al., 2012). Being a rather novel concept in natural hazard management, this understanding of social capacities has been further elaborated, but applied in only a very few conceptual and empirical studies (Höppner et al., 2012). Therefore, for our study on social capacities of drought risk management in Switzerland, we draw on different strands of literature from vulnerability studies, climate adaptation sciences and social-ecological resilience research, where capacities have been conceptualised for more than a decade. Many scholars build upon a systematisation, which was labelled "adaptive capacities determinants of climate change" in the third assessment report by the Intergovernmental Panel on Climate Change (IPCC) (Smit and Pilifosova, 2001) and later elaborated in a broad range of thematically related studies (Yohe and Tol, 2002; Brooks et al., 2005; Smit and Wandel, 2006; Armitage and Plummer, 2010; Engle and Lemos, 2010; Glaas et al., 2010; Gupta et al., 2010; Engle, 2011; Keskitalo et al., 2011; Hill, 2013). Adaptive capacity is often understood as the ability or potential of a system to respond successfully to climate variability and change (Smit and Pilifosova, 2001). Thus, adaptive capacities follow a system-related approach where social actors are embedded in a social, economic and ecological context that forms their abilities to respond to change. Different scholars have described various sets of determinants or dimensions of adaptive capacity. Smit and Pilifosova (2001) for example identify six dimensions (economic resources, technology, information and skills, infrastructure, institutions, equity), Yohe and Tol (2002) eight (technology, resources, institutions, human capital, social capital, risk management, information management, attributing signals of change to their sources), Brooks et al. (2005) also eight (economic wellbeing and inequality, health and nutritional status, education, physical infrastructure, governance, geographic and demographic factors, agriculture, ecosystems and technological capacity) to name only a few. In the last years a set of five determinants has been established for characterising adaptive capacity in the European context which synthesises most of the earlier determinants (Keskitalo et al., 2011; Juhola and Kruse, 2013). We will apply it in the study presented here. The set includes knowledge and information, technology and infrastructure, economic resources, organisation and management, policies and institutions. Knowledge and information embraces skills and abilities that are linked to the knowledge and information available for individuals, organisations and social groups that can be enhanced by training, research or ready to use guidelines. Technology and infrastructure imply abilities or resources that enable organisations of social groups to use or implement technical or infrastructural means to support drought risk management (e.g. monitoring and information systems, pipelines for fire fighting). Organisation and management refers to skills and abilities related to economic activities as well as public administration, including e.g. diversification, sharing responsibilities or

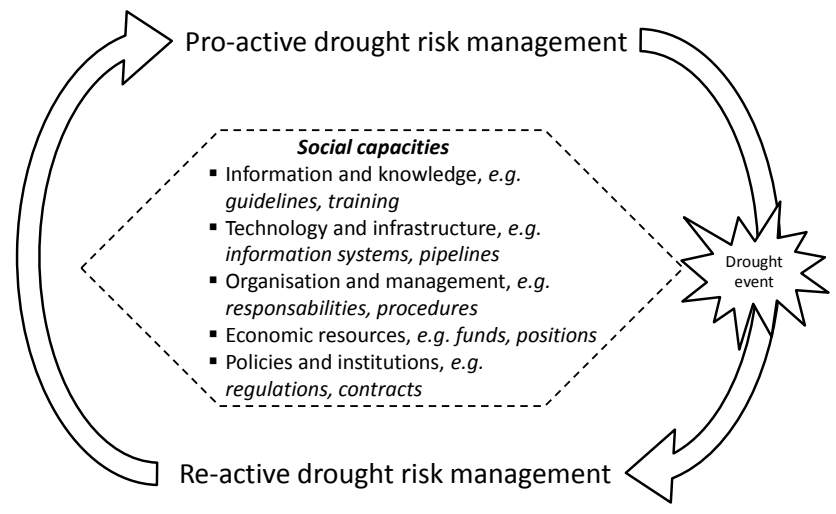

Fig. 1. General social capacities for drought risk management.

implementing procedures such as emergency plans. The dimension economic resources implies that there are economic or financial capacities to maintain or bring forward drought risk management (e.g. recovery funds or insurances). The dimension policies and institutions involves institutional support for drought risk management, e.g. in the form of laws, legally binding instruments or regulations. For our study we consider these five determinants as dimensions of adaptive capacity that enable an integrated analysis of adaptive capacities within the disaster management cycle, considering not only the abilities of social actors but also taking into account the resources provided through the regulatory or governance system of a country, the economy, the cultural setting and ecological preconditions. An integrated drought risk management should ideally combine all five dimensions of social capacities. Accordingly, we use the heuristic framework depicted in Fig. 1 for leading the study and presenting the results. We consider the dimensions interrelated and assume that they can be modified within the disaster management cycle (Smit and Wandel, 2006). Also, we label them "dimensions" to highlight the variance in possible characteristics, and we label them "social" referring to the concept of social construction of reality (Berger and Luckmann, 1967). To us, linking the concept of social capacities with the dimensions of adaptive capacities specifies the concept of social capacities as it widens the focus on the individual, social group or organisation by including the social system they act in. With this we contribute to the ongoing debate about social capacities in natural hazard management (Kuhlicke et al., 2011).

The concept of adaptive capacity resembles the understanding of social capacities in natural hazard management, the former having been applied and specified in a large number of studies. Preston et al. (2011) emphasise that adaptive capacities need to be specified according to the specific context of the analysis, in our case to drought risk management. Therefore we assume that drought risk management involves a set of specific capacities that can be grouped along these five dimensions. So far, there has been some empirical research on capacities for drought risk management, mostly in 
Table 1. General social capacities for drought risk management.

\begin{tabular}{ll}
\hline Social capacity dimensions & Examples for social capacities for drought risk management \\
\hline 1. Information and knowledge & $\begin{array}{l}\text { Drought information tools and capacities for early recognition (Vicente-Serrano et al., 2012); } \\
\text { education and training of farmers; problem awareness (Murendo et al., 2011). }\end{array}$ \\
$\begin{array}{ll}\text { 2. Technology and infrastructure } \\
\text { 3. Organisation and management supply infrastructure; irrigation systems; fire fighting equipment (Wittrock et al., 2011). }\end{array}$ & $\begin{array}{l}\text { Adapting soil and water conservation practices (Murendo et al., 2011), } \\
\text { diversification of economic activities. }\end{array}$ \\
& $\begin{array}{l}\text { Diversified income, insurances (Wittrock et al., 2011), funds, positions. } \\
\text { 4. Economic resources }\end{array}$ \\
$\begin{array}{l}\text { 5. Policies and institutions } \\
\text { for water withdrawal; catchment management authority (Nelson et al., 2008; Iglesias et al., 2011). }\end{array}$
\end{tabular}

areas highly affected by drought risks, i.e. in Africa, Australia, the United States and the Mediterranean region. These studies exemplify possible social capacities for drought risk management (cf. Table 1). For instance, a study on drought risk management in Africa emphasises the need for drought information tools for effective proactive drought risk management (Vicente-Serrano et al., 2012). A case study in Ethiopia came to the conclusion that professional training of farmers and changes in agricultural practices, e.g. soil and water conservation practices, are key capacities to adapt to and cope with droughts (Murendo et al., 2011). In a comparative study of three rural communities in the Canadian prairie, Wittrock et al. (2011) identified water supply infrastructure and a diversified income base as the most important capacities for decreasing the vulnerability to droughts. In their investigation of drought risk management in Australia, Nelson et al. (2008) stress the need for drought policies capable of integrating local knowledge and institutions that enable the management of water as a common property resource (e.g. catchment management authorities). Also Iglesias et al. (2011) stress the need for socially and economically sensitive policies in order to prevent inequalities in the view of climate change in the Mediterranean region.

\section{Methods}

Based on the conceptual framework developed in Sect. 2, we assume in our empirical study that capacities, i.e. the abilities, skills and internal resources to successfully anticipate and respond to external stressors, are a prerequisite to carry out drought risk measures. Further, we assume that measures to manage drought risks (e.g. drought information tools, training of farmers, adapted agricultural practices, diversified income or socially and economically sensitive polices) can be associated to the five dimensions of social capacities. Based on these assumptions we investigate the social capacities by inquiring and evaluating drought risk measures that have been implemented. The results presented in this paper are based on two studies conducted between 2010 and 2012 (for details refer to Table 2). With our empirical research we base our results on the opinions and experiences of water users and decision-makers.

In the first study we investigated social capacities from the perspective of water users with a focus on drought risk mitigation and response measures, and proceeded in two steps. In a first step we administered a survey questionnaire to fifteen representatives of water user groups. We asked which measures they implemented to mitigate or reduce droughtinduced damage and which information they need for realising those measures. The survey questionnaire was designed to prepare an expert workshop with thirteen representatives of the different water user groups where we discussed and specified the results. In a second step we investigated the effectiveness of different proactive and reactive measures for the reduction of drought risks by conducting nine qualitative interviews with representatives from three economic sectors affected by droughts: agriculture (focusing on irrigation in fruit growing), forestry (focusing on prevention of forest fire), and the energy sector (focusing on hydro power production). Here, we were interested in the interviewees' evaluation of applied or potential drought risk measures.

In the second study we investigated the social capacities for drought risk management with a focus on the institutional- and policy context supporting drought risk management. We conducted nine expert interviews and administered a questionnaire survey to 32 representatives of cantonal authorities for the environment, national agencies and associations as well as research institutes from applied sciences. The drought event of 2003 served as a reference event and a set of questions focussed on the participants' perception and evaluation of the changes in drought risk management and lessons learned after the experiences of 2003.

For both studies we chose an exploratory and qualitative research design for two reasons: first, drought risk management is a rather new approach in Switzerland; and second, there is not a large population of water users and relevant policy- and decision-makers of national and cantonal level. Thus for the first study, we conducted interviews and surveys with representatives of water user groups from different economic sectors potentially sensitive to droughts: agriculture (considering farming, vegetable growing, fruit growing), 
Table 2. Overview over the methods used, including main questions asked in interviews, workshop and surveys.

\begin{tabular}{|c|c|c|c|}
\hline \multicolumn{2}{|r|}{ Methods used } & Main questions asked & Participants \\
\hline \multirow{3}{*}{ 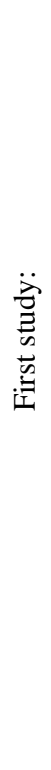 } & $\begin{array}{l}\text { survey } \\
\text { questionnaire }\end{array}$ & $\begin{array}{l}\text { Please define drought from the perspective of the water } \\
\text { user group you are representing. } \\
\text { When is a drought critical and what are the consequences? } \\
\text { What measures do you take to mitigate damages when } \\
\text { you recognise a drought early? } \\
\text { Which information systems do you use to recognise droughts early? }\end{array}$ & $\begin{array}{l}N=15 \text { (return rate: } 66 \% \text { ): } \\
\text { representatives from the water } \\
\text { user groups: agriculture, } \\
\text { forestry, water supply, } \\
\text { shipping industry, } \\
\text { fishery and tourism }\end{array}$ \\
\hline & $\begin{array}{l}\text { expert } \\
\text { workshop }\end{array}$ & $\begin{array}{l}\text { Please define drought from your perspective. } \\
\text { How relevant have droughts been in the past for the water } \\
\text { user group you are representing? } \\
\text { What information is available and what do you need for } \\
\text { early recognition of a drought? } \\
\text { When is early recognition successful? }\end{array}$ & $\begin{array}{l}N=14 \text { : representatives from } \\
\text { the water user groups: } \\
\text { agriculture, forestry, } \\
\text { water supply, hydro power, } \\
\text { shipping industry, fishery, } \\
\text { ecology }\end{array}$ \\
\hline & $\begin{array}{l}\text { expert } \\
\text { interview }\end{array}$ & $\begin{array}{l}\text { What impacts do droughts have in your field of } \\
\text { practice? What damages occur? } \\
\text { Which strategies and measures are implemented in your economic } \\
\text { sector to mitigate or reduce damage? } \\
\text { Which economic benefits does early recognition of } \\
\text { droughts have in your economic sector? }\end{array}$ & $\begin{array}{l}N=9 \text {, practitioners and } \\
\text { decision-makers from } \\
\text { three economic sectors: } \\
\text { agriculture (fruit growing), } \\
\text { energy production (hydropower), } \\
\text { and forestry (forest fire prevention) }\end{array}$ \\
\hline 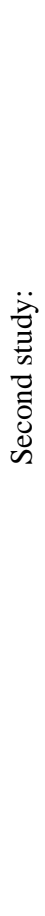 & $\begin{array}{l}\text { expert } \\
\text { interviews }\end{array}$ & $\begin{array}{l}\text { In your opinion, is the existing regulatory framework adequate } \\
\text { and sufficient to ensure an effective response to drought? } \\
\text { To what extent are other related sector policies integrated into } \\
\text { the existing drought policy? } \\
\text { Do you think the financial and personnel resources allocated for } \\
\text { drought management in the } 2003 \text { drought event were sufficient? } \\
\text { Was there enough personnel assigned to drought management in your } \\
\text { sector and were they sufficiently trained? } \\
\text { Do you think that the level of stakeholder participation in the } \\
\text { decision-making processes related to the } 2003 \text { drought was adequate? } \\
\text { In your opinion, which measures worked best and } \\
\text { worst during the } 2003 \text { drought? } \\
\text { Were there any recovery measures after the } 2003 \text { drought? If yes, } \\
\text { how adequate were they? } \\
\text { Are there any other measures that could have been implemented to } \\
\text { reduce impacts of the } 2003 \text { drought? } \\
\text { How would you score the following aspects (i.e. coordination, } \\
\text { participation, information and communication, planning and } \\
\text { preparedness, etc.) of drought management during the } 2003 \text { drought? } \\
\text { (Scores: very adequate, adequate, not so adequate, } \\
\text { inadequate, I don't know/not applicable) } \\
\text { In your opinion, was there something learnt by } \\
\text { the drought period in } 2003 \text { for future drought management? }\end{array}$ & $\begin{array}{l}N=32 \text { (return rate: } 44 \% \text { ): } \\
\text { representatives of cantonal } \\
\text { authorities for environment, } \\
\text { national agencies and } \\
\text { associations, applied sciences }\end{array}$ \\
\hline
\end{tabular}

forestry, water supply, shipping industry, fishery and tourism on the one hand. On the other hand, we conducted an in depth study in three economic sectors (agriculture, forestry and energy), as scholars have previously outlined that drought impacts differ between different groups and thus group-specific methodology is recommended (cf. Kallis, 2008). We chose agriculture, forestry and energy as the survey showed that all three sectors have been impacted by droughts in the past and are of economic and social relevance for many regions in Switzerland. At the same time the sectors show different characteristics concerning the actors managing drought and scale of action. While drought risk in the agricultural sector is managed on a small scale level by private actors, in the energy sector large private companies are more interrelated 
with the European market. In the forestry sector drought management is mostly conducted by public actors, i.e. cantonal authorities. They implement drought mitigation measures not only to prevent economic losses in timber production, but more often to mitigate secondary damages in the protective function of forests in Switzerland against natural hazards.

For the second study the sample of interviewees and survey participants (overall 41 persons) included experts from national or regional associations, private companies, public administration, civil society and applied sciences as well as from all regions in Switzerland (northwest-, east- and central-Switzerland, French-speaking Switzerland and Ticino). Both the workshop and the interviews were recorded in writing and partly audio-recorded and transcribed. The data of the survey questionnaire included open questions that were analysed according to methods of qualitative content analysis, i.e. inductive formulation of categories, coding of the text along categories, qualitative analysis and interpretation of results (Mayring, 2010). For answering the research questions all data was considered.

\section{Results}

The survey and interview studies with different water user groups in three economic sectors showed that water users have a range of existing mitigation and response measures at hand which they carry out in the case of droughts and low flow conditions. These measures are specific for each water user group and can be structured along the dimensions of social capacities (cf. Table 3). In summary, the results show that the survey participants and interviewees consider the capacities for reactive crisis management overall as rather sufficient, but see some deficits in proactive strategic drought management. In what follows, we present the results with regard to the framework introduced in Sect. 2, along the five dimensions of social capacities for proactive drought management (cf. Sect. 4.1) and reactive drought risk management (cf. Sect. 4.2).

\subsection{Social capacities for proactive drought risk management in Switzerland}

The results on the existing social capacities for proactive drought risk management in Switzerland from the perspective of water users and policy makers are summarised in Table 4. Concerning the first dimension, information and knowledge, the surveys and interviews show that drought information is considered an important basis for proactive drought risk management. The interviewees and respondents state that monitoring and information systems for different meteorological and hydrological variables (for example precipitation, air temperature, ground water level, surface water level, run-off, snow water equivalent) are available in Switzerland, although until recently (June 2013) they were not accessible in an integrated drought information system for the water users. The survey and workshop of the first study showed that this drought information system would need to include a large set of drought variables if it is to satisfy the information requirements of the different water user groups (Kruse et al., 2010; Seneviratne et al., 2013). Furthermore, the study showed that the different water user groups require not only specific drought variables, they also have different needs concerning the spatial resolution of drought information, the prediction period and the accuracy of predictions (cf. Table 5). Also, the monitoring of water availability, water usage and water distribution is not established as a standard procedure in the municipalities and cantons. Another challenge for proactive drought management is the transfer of drought information into drought mitigation activities. Some interviewees stress that there is still a low problem awareness concerning drought impacts in Switzerland. Until droughts occur more often, seemingly many water users will react as follows:

RESPONDENT. One cannot do much about it. If it is dry, it is just dry. ${ }^{1}$

Establishing infrastructure for drought risk management (e.g. irrigation systems, water storage capacity, water infrastructure for fire fighting), the second dimension of social capacities, again can be seen as an important prerequisite for proactive drought management. It demands long-term planning which needs to be embedded in strategic management decisions. The interviewees stress that for investments on infrastructure they need robust information about future development of drought risks. This is in many aspects still a challenge for the climate sciences, though many studies predict an increase of droughts in some parts of Switzerland (Rebetez, 1999; Beniston and Stephenson, 2004; Reinhard et al., 2005). Additionally, some interview statements hint at the fact that some water users have a disbelief in these studies as long as droughts do not occur more often.

The investigation showed that organisation and management, the third dimension of social capacities, are important for proactive drought risk management. This concerns for instance the diversification of economic activities (products, branches and sites), e.g. in agriculture and hydropower production. In general, the more diverse a production, the less vulnerable the business is to drought situations. The interviews revealed that for now, diversification relevant for proactive drought management exists, but has not been implemented primarily due to drought risks, but due to general management risks of the business. Hence, measures in the field of organisation and management have synergies with other goals of a farm or company. Thus, drought risk management is ideally embedded in the overall management strategies.

\footnotetext{
${ }^{1}$ Interview with a representative of a Swiss water association, 11 June 2012
} 
Table 3. Overview on proactive and reactive drought risk measures in three selected water user groups in Switzerland ( ${ }^{\mathrm{a}}$ proactive measures;

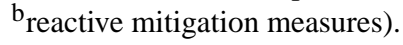

\begin{tabular}{|c|c|c|c|}
\hline \multirow{2}{*}{$\begin{array}{l}\text { Social capacity } \\
\text { dimensions }\end{array}$} & \multicolumn{3}{|c|}{ Drought risk measures per water user group } \\
\hline & Agriculture (fruit growing) & Energy production (hydropower) & Forestry (forest fire prevention) \\
\hline $\begin{array}{l}\text { Information and } \\
\text { knowledge }\end{array}$ & $\begin{array}{l}\text { Monitoring of precipitation } \\
\text { and soil moisture on the site; } \\
\text { public weather services }{ }^{b}\end{array}$ & $\begin{array}{l}\text { Forecasting of run-off } \\
\text { and precipitation }{ }^{b}\end{array}$ & $\begin{array}{l}\text { Daily drought maps in some Cantons, } \\
\text { processing weather forecast and } \\
\text { local knowledge }^{b}\end{array}$ \\
\hline $\begin{array}{l}\text { Technology and } \\
\text { infrastructure }\end{array}$ & Irrigation systems $^{\mathrm{a}}$ & Increase of pump storage capacity ${ }^{a}$ & Water infrastructure for fire-fighting ${ }^{\mathrm{a}}$ \\
\hline \multirow[t]{2}{*}{$\begin{array}{l}\text { Organisation and } \\
\text { management }\end{array}$} & Soil treatment ${ }^{b}$ & Management of turbine operation ${ }^{b}$ & $\begin{array}{l}\text { Stand-by for emergency response } \\
\text { duties (helicopter) }\end{array}$ \\
\hline & Diversification of crops ${ }^{\mathrm{a}}$ & Regional/operational diversification $^{\mathrm{a}}$ & $\begin{array}{l}\text { Management of burnt material }{ }^{b} \\
\text { Long-term risk evaluation }^{\mathrm{a}}\end{array}$ \\
\hline Economic resources & Hedging of risks ${ }^{b}$ & Hedging of risks ${ }^{b}$ & $\begin{array}{l}\text { No fire insurances in place, } \\
\text { instead regional funds for firefighting }\end{array}$ \\
\hline $\begin{array}{l}\text { Policies and } \\
\text { institutions }\end{array}$ & Subsidies for irrigation $^{\mathrm{a}}$ & $\begin{array}{l}\text { Contracting of concessions on } \\
\text { the amount of water to be used for } \\
\text { hydropower production }^{\mathrm{a}}\end{array}$ & $\begin{array}{l}\text { Fire bans (permanent/temporary) } \\
\text { federal regulation for warning } \\
\text { fed }^{\mathrm{a}}\end{array}$ \\
\hline
\end{tabular}

Table 4. State of social capacities for proactive drought risk management in Switzerland.

\begin{tabular}{ll}
\hline Social capacity dimensions & State of proactive drought risk management in Switzerland \\
\hline Information and knowledge & $\begin{array}{l}\text { Broad set of drought-relevant information available, integrated in a drought information system in June 2013. } \\
\text { Low drought risk awareness. }\end{array}$ \\
Technology and infrastructure & $\begin{array}{l}\text { Long-term strategies needed for investments in technology and infrastructure } \\
\text { for increasing mitigation and preparedness. } \\
\text { Organisation and management } \\
\text { Lconomic resources }\end{array}$ \\
Policies and institutions & $\begin{array}{l}\text { Sufficient resources available (under the premise of rare intervals of drought events). } \\
\text { Institutional framework for mitigation and preparedness is fragmented; } \\
\text { some potential is seen in the integration of droughts in existing natural hazard and } \\
\text { water management policies and institutions. }\end{array}$ \\
\hline
\end{tabular}

According to the interviewees, the economic resources, the fourth dimension of capacities for proactive drought management, seem to be sufficiently established. Nevertheless, this has to be seen in the context that, until this point, proactive drought risk management has not been a priority to water user groups in Switzerland and only a few high-cost investments have been made so far; for example setting up a forest fire monitoring system is still in the pilot phase in some regions.

Regarding the fifth dimension, policies and institutions, many interviewees criticise that up to now a coherent, integrated drought risk management and strategy for dealing with water scarcity has been missing. The regulations governing the usage and withdrawal of water in times of water scarcity resemble - following an interviewee - a "rag rug" rather than a coherent institutional framework ${ }^{2}$. Many interviewees see the main barriers for developing an institutional framework for drought risk management in the federal and subsidiary system of water relevant regulations. For this, it is important to know that the withdrawal of water is governed by the canton or by the communities in the case of temporary water withdrawal facilities. Up to now, there are no nation-wide comprehensive guidelines for the approval of water withdrawal, for prioritising certain water users or for monitoring the amount of water withdrawal. During past droughts, this has led to conflicts between different water user groups and across municipal and cantonal boundaries within a watershed (Schneider and Homewood, 2013). At the same time, policy and institutional capacities in Switzerland

\footnotetext{
${ }^{2}$ Interviewee from a network of Swiss water supply and distribution companies.
} 


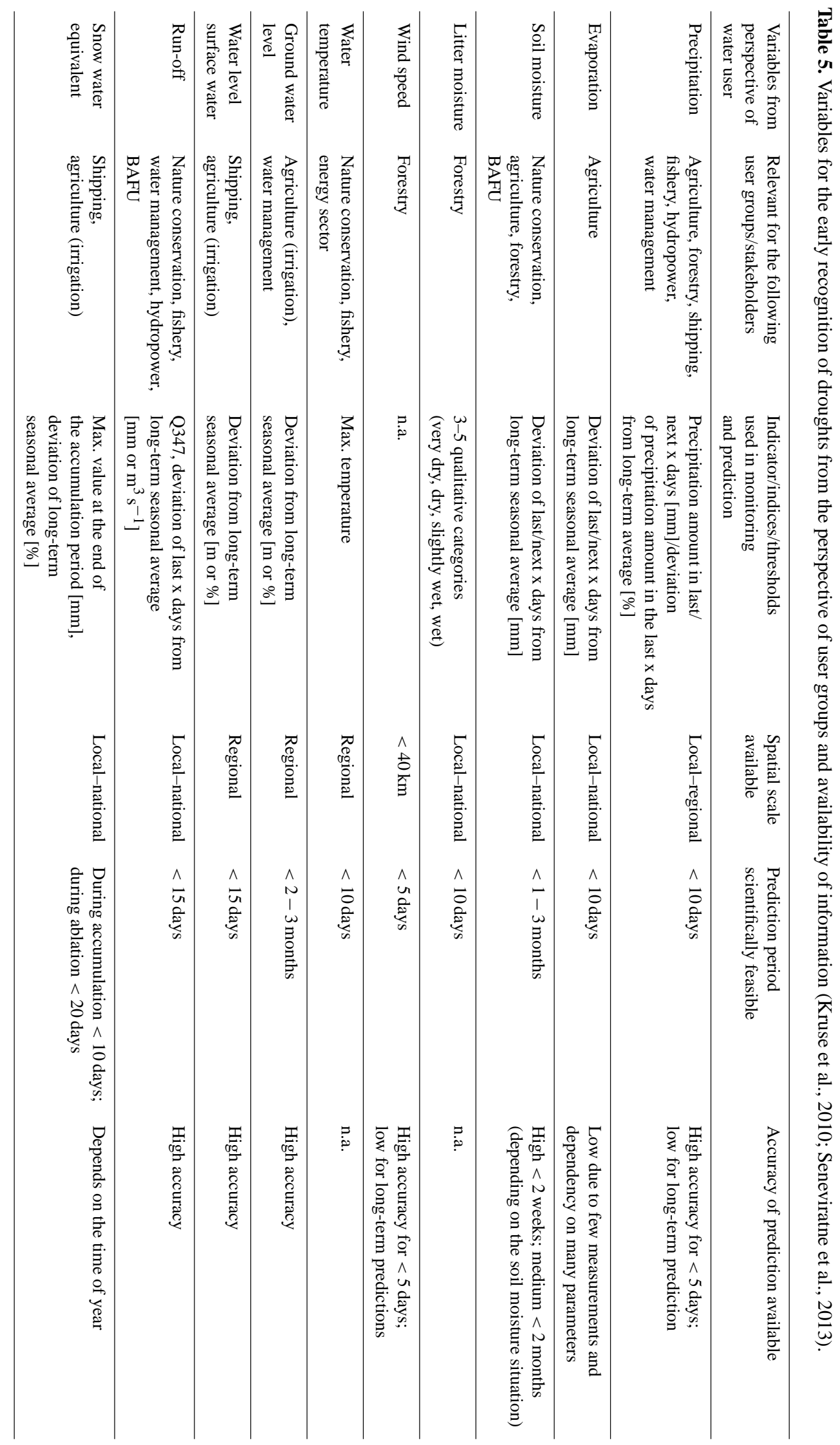


can build upon a long tradition and experience of natural hazard management (e.g. flood management) as well as water management (e.g. integrated watershed management) that established for example efficient inter-cantonal cooperation. Moreover, this cooperation is constantly strengthened by new initiatives, e.g. the inter-cantonal early warning and crisis information system (IFKIS) and the resolution for optimisation of warning and alerting (OWARNA) (Willi, 2007). Some interviewees believe that as soon as droughts occur more often and public attention rises, policies and regulations for drought risk management will be established and integrated in the existing institutional framework of natural hazard management. The initiative of a parliamentarian to develop a strategy for the management of local water scarcity in Switzerland, prompted by the drought event of 2003, and the resulting report on this initiative supports this estimation (BAFU, 2012b).

\subsection{Social capacities for reactive drought risk management in Switzerland}

The results on the existing and missing social capacities for reactive drought risk management in Switzerland from the perspective of the water users and policy makers are summarised in Table 6. Concerning the first dimension, information and knowledge, the survey and workshop of the first study showed that an integrated drought information system including both hydro-meteorological drought variables and social and economic impact variables is currently missing in Switzerland, but would be one of the most important prerequisites for effective drought impact assessment (a pilot information platform assembling hydro-meteorological drought variables has been set up in June 2013; www.drought.ch). Yet, the survey among cantonal and national policy- and decision-makers revealed that the monitoring of economic and social impacts of droughts is still an exception. When it comes to knowledge, the answers to the interview questions evaluating the drought mitigation measures show that importance lies not only with information, but also the local knowledge about impacts, held by experts familiar with the respective sites and local conditions (e.g. farmers, hydropower operators or foresters), in order to evaluate the drought impacts and arrange corresponding response measures (cf. Table 3 ).

The technological and infrastructural capacities for reactive drought response in Switzerland, the second dimension, have been rather limited so far according to the interviewees and respondents. During the drought event in 2003, mobile irrigation was supported by water tankers provided by the army and local fire brigades. In a region of the Valais that was not sufficiently equipped to extinguish forest fires, a fire expanded and caused massive damages and recovery costs (Moretti and Conedera, 2003).

Concerning organisation and management, the third dimension, in the respondents' opinion the extreme drought event in 2003 demonstrated that there were enough per- sonnel to organise and manage emergency and drought defence measures (e.g. irrigation of crops, distribution of drinking water, emergency service for forest fire). In some parts of Switzerland the army and community services supported farmers with irrigating the crops. Yet, the respondents stated that other than on the national and cantonal level, on the local level there was not enough personnel for nominating a drought delegate in most of the affected communities. Consequently, local officers had to work overtime to coordinate drought defence measures, but as one interviewee puts it:

RESPONDENT. [...] people have a high motivation, especially in this kind of situation. Therefore, it always has worked so far. ${ }^{3}$

The cooperation between the cantons, the involvement of national and regional associations (e.g. farmers associations) and solidarity among farmers and the population was evaluated positively.

According to the interviews of the second study, the fourth dimension, the economic capacities and financial means available for crisis management in reaction to drought events are considered sufficient;

RESPONDENT. If there is a drought event, one changes his priorities $[\ldots]$ and authorises the resources. ${ }^{4}$

Yet, this may be the case only as long as droughts remain a rare phenomenon.

Also regarding the dimension of institutions and policies, the survey participants and interviewees of the second study evaluate the capacities as sufficient. They state that the emergency measures were also implemented in a flexible way across administrative borders during the drought 2003. Again, the high state of regulations for emergency response in natural hazard management in general might have supported this reaction.

\section{Discussion: implications for building capacities for drought risk management in Switzerland}

The results show that from the perspective of water users and decision-makers, the situation of social capacities is as follows: in order to proactively manage drought risks management, capacities such as information and knowledge and economic resources generally are available; yet, capacities such as technology, infrastructure as well as organisation and management are insufficient for proactive drought management. The institutional framework for proactive management is fragmented, and an integration of drought risk management in existing hazard management policies and institutions is perceived as promising.

For reactive drought risk management the picture is more positive as the water users and decision-makers perceive

\footnotetext{
${ }^{3}$ Interview with a representative of a Swiss water association, 12 June 2012.

${ }^{4}$ According to one interview from an authority for agriculture, 21 June 2012.
} 
Table 6. State of social capacities for reactive drought risk management in Switzerland.

\begin{tabular}{ll}
\hline Social capacity dimensions & State of reactive drought risk management in Switzerland \\
\hline Information and knowledge & - Integrated drought information system needed \\
& - Monitoring of social and economic impacts an exception \\
& - Local knowledge important for the risk assessment - partly missing \\
Technology and infrastructure & - Technology and infrastructure for crisis management available but rather limited \\
Organisation and management & - Enough personnel available \\
& - Effective coordination and cooperation \\
Economic resources & - Sufficient financial means available for crisis management \\
& (under the premise of rare intervals of drought events) \\
Policies and institutions & - Policies and institutions for emergency measures sufficient \\
& (under the premise of rare intervals of drought events) \\
\hline
\end{tabular}

that technology, infrastructure, personnel and economic resources are sufficiently available to cope with emergency and crisis situations. Only concerning information and knowledge, an integrated drought information system is considered as necessary in order to enable monitoring not only of the drought situation but also of social and economic impacts.

Thus overall, the results depict a moderate state of social capacities regarding drought risk management resulting in an early stage in proactive and reactive drought management in Switzerland, although the latter is more advanced than the former. The various sources we used are consistent regarding this conclusion.

This conclusion is not surprising for two reasons: first, drought is not (yet) a pressing problem but rather a rare natural hazard in Switzerland. This also explains why the survey participants and interviewees consider today's infrastructure, economic resources and organisational and management capacities as sufficient. Yet, in terms of capacity building these capacities would need to be extended in the case of more frequent droughts. Second, Switzerland has a long-standing tradition in integrated risk management of natural hazards (especially floods, mudflows, avalanches, rockslides, etc.) which the evolving drought risk management draws upon. Hence, in crisis situations some reactive drought risk measures can easily and quickly be established, as was the case in the drought event in 2003. At the same time, the water users and policy- and decision-makers express some alertness regarding the need to develop specific strategies for managing drought risks. Especially, public agencies on the national level recognised the need and have recently developed a rough strategy for how to deal with water scarcity in Switzerland (including measures for exceptional situations and for long-term provision, BAFU, 2012b). This strategy is planned to be followed by various activities such as the identification of drought risk areas, management plans for water resources in drought risk areas and the development of a code of practice with examples on how to settle conflicts on water issues (BAFU, 2012b).
Regarding the implications for building social capacities we conclude that urgency due to looming drought events is an important ingredient. The results suggest that the process of building social capacities may be accelerated through drawing on capacities that already exist in related fields (i.e. natural hazard risk management), upon experience from single cantons (e.g. fire risk management in Ticino), through taking notice of research - ideally of scientists from one's own country - and through raising awareness of historical events and management strategies such as the Suones (traditional water channels for irrigation) or the common property management of water resources which is still alive in the neighbouring Vinschgau (Italy). Most important is a national coordination and framework that spurs cantons and municipalities to carry out their duties, avoids duplication and places importance on drought risk.

In our research we analysed the perception, i.e. the opinions and experiences, of drought risk management in Switzerland by water users and policy- and decision-makers. As we conclude from the drought risk measures to the capacities (cf. Sect. 3), the evaluation of the capacities is on the one hand our interpretation and on the other hand needs to be seen within the context the respondents draw upon. This context may be the drought risk situation and management which varies among the regions and cantons - and the level of nationwide natural hazard risk management - which is quite high in general. For example in the fire-prone canton of Ticino social capacities regarding forest fires are highly developed. Since the 1990s and as a result of legislative, technical and organisational measures, damages from forest fires and the amount of burnt area have decreased, even during 2003 (Pezzatti et al., 2013). In other regions where forest fires are rather uncommon, both policies and regulations as well as technical and organisational measures are poorly developed.

Regarding the methods chosen in the studies presented here the following remarks need to be made: given the fact that stakeholders might have only very few experiences with drought events, an assessment focusing on stakeholders perspectives only might be limited, as their perspective might be 
blurred, limited or subjective. Nevertheless, as drought risk management is a rather new topic for Switzerland, we believe that only an explorative research design is possible to evaluate the status of social capacities for drought risk management, and detecting the first starting points for building those capacities. Therefore, we selected representatives of water user groups and decision-makers mainly from associations and authorities as interviewees and survey participants because their views are most likely to stand for those of the stakeholder group they are representing. Also, where possible we chose representatives that have been involved for a longer period of time so that they can judge the situation against the background of experiences. Thus, we believe that the methods we used allow both an overview and a substantial insight into the topic. With their limitation though they do not deliver an in-depth evaluation of the capacities and options for building capacities but enable the identification of starting points for building capacities and conducting future research. A problem of an investigation that concerns the Swiss-wide situation is the variety in cantonal and local contexts both regarding drought risks and their management. Further, only a few droughts occurred in the last decades, which limits the analysis of the performance of drought risk management. In our survey and interview study, we faced the problem of partly limited information regarding drought management in 2003, as either people do not remember or are retired. Future studies should take the opportunity of the next drought event and conduct a formative evaluation of the drought risk management at different points in time (e.g. during or shortly after the event, one year later, five years later).

\section{Conclusions}

In order to build up and implement an integrated drought risk management in Switzerland social capacities need to be enhanced and developed. Although valuable preconditions regarding the five dimensions of social capacities are available, we see a particular need to assemble the available data in an integrated information system, to expand technologies and infrastructure for proactive capacities, not to dwell on hitherto successful ad-hoc management but to develop long-term strategies, to be ready to expand financial resources and to coordinate better institutions and policies which so far are fragmented.

Though Switzerland definitely is not at the top of drought risk management compared to countries such as Spain, Italy or even the Netherlands (Ministry of Infrastructure and the Environment, 2012), and though Switzerland is constitutionally in a particular institutional and cultural situation, the results may be of interest for other developed countries which are confronted with increasing drought risks. Useful for building social capacities for drought risk management, it seems to draw on other natural hazard risk management frameworks and experience, to use existing relevant data and to invest in monitoring the missing data, including social and economic impacts, to give importance to regional and local knowledge and experience and finally, to overcome an institutional rag rug through consistent regulations and coordination.

Acknowledgements. We thank all interviewees, Claudia Keller for conducting a part of the interviews and one of the surveys, colleagues from Drought-CH and Drought R\&SPI, Annett Steinführer and the two anonymous referees.

Edited by: A. Steinführer

Reviewed by: two anonymous referees

\section{References}

Armitage, D. and Plummer, R.: Adapting and transforming: Governance for navigating change, in: Adaptive capacity and environmental governance, edited by: Armitage, D. and Plummer, R., Springer series on environmental management, Springer Berlin Heidelberg, 287-302, 2010.

BAFU (Bundesamt für Umwelt): Anpassung an den Klimawandel in der Schweiz Ziele, Herausforderungen und Handlungsfelder. Erster Teil der Strategie des Bundesrates vom 2. März 2012, Bern, Switzerland, 2012a (in German).

BAFU (Bundesamt für Umwelt): Umgang mit lokaler Wasserknappheit in der Schweiz. Bericht des Bundesrates zum Postulat "Wasser und Landwirtschaft. Zukünftige Herausforderungen", (Postulat 10.353 von Nationalrat Hansjörg Walter vom 17. Juni 2010), 2012b (in German).

Berger, P. M. and Luckmann, T.: The Social Construction of Reality: A Treatise in the Sociology of Knowledge, Anchor Books, New York, 1967.

Beniston, M.: Linking extreme climate events and economic impacts: Examples from the Swiss Alps, Energ. Policy, 35, 53845392, 2007.

Beniston, M. and Stephenson, D. B.: Extreme climatic events and their evolution under changing climatic conditions, Global Planet. Change, 44, 1-9, 2004.

BLW (Bundesamt für Landwirtschaft): Klimastrategie Landwirtschaft. Klimaschutz und Anpassung an den Klimawandel für eine nachhaltige Schweizer Land- und Ernährungswirtschaft, Referenz/Aktenzeichen: 2011-05-26/138/fed, 2011 (in German).

Bradford, R. B.: Drought events in Europe, in: Drought and Drought Mitigation in Europe, edited by: Vogt, J. V. and Somma, F., Kluwer Academic Publishers, Dordrecht, The Netherlands, 722, 2000.

Brooks, N., Adger, W. N., and Kelly, P. M.: The determinants of vulnerability and adaptive capacity at the national level and the implications for adaptation, Global Environ. Chang., 15, 151163, 2005.

BUWAL, BWG, and MeteoSchweiz: Auswirkungen des Hitzesommers 2003 auf die Gewässer, Schriftenreihe Umwelt Nr. 369, Bundesamt für Umwelt, Wald und Landschaft, Bern, 2004 (in German).

Collet, L. and von Niederhäusern, A.: Bewässerungsbedarf, saisonaler Wassermangel und Bewässerungswürdigkeit bei 
Gemüsekulturen im Grossen Moos, Kantonale Zentralstelle für Gemüsebau Freiburg (KZG FR), 2008 (in German).

EEA: Climate change impacts and adaptation in the European alps: Focus water resources, Copenhagen, 2009.

Engle, N. L.: Adaptive capacity and its assessment, Global Environ. Chang., 21, 647-656, 2011.

Engle, N. L. and Lemos, M. C.: Unpacking governance: Building adaptive capacity to climate change of river basins in Brazil, Global Environ. Chang., 20, 4-13, 2010.

Fuhrer, J., Beniston, M., Fischlin, A., Frei, C., Goyette, S., Jasper, K., and Pfister, C.: Climate risks and their impact on agriculture and forests in Switzerland, Climatic Change, 79, 79-102, 2006.

Glaas, E., Jonsson, A., Hjerpe, M., and Andersson-Sköld, Y.: Managing climate change vulnerabilities: Formal institutions and knowledge use as determinants of adaptive capacity at the local level in Sweden, Local Environment: The International Journal of Justice and Sustainability, 15, 525-539, 2010.

Gupta, J., Termeer, C., Klostermann, J., Meijerink, S., van den Brink, M., Jong, P., Nooteboom, S., and Bergsma, E.: The adaptive capacity wheel: A method to assess the inherent characteristics of institutions to enable the adaptive capacity of society, Environ. Sci. Policy, 13, 459-471, 2010.

Hill, M.: Climate Change and Water Governance. Adaptive Capacity in Chile and Switzerland, Springer, Dordrecht, The Netherlands, 2013.

Höppner, C., Whittle, R., Bründl, M., and Buchecker, M.: Linking social capacities and risk communication in Europe: A gap between theory and practice?, Nat. Hazards, 64, 1753-1778, 2012.

Iglesias, A., Garrote, L., Diz, A., Schlickenrieder, J., and MartinCarrasco, F.: Re-thinking water policy priorities in the Mediterranean region in view of climate change, Environ. Sci. Policy, 14, 744-757, 2011.

Juhola, S. and Kruse, S: A Framework for Analysing Regional Adaptive Capacity Assessments: Challenges for Methodology and Policy Making, Mitigation and Adaptation Strategies for Global Change, online first, doi:10.1007/s11027-013-9481-z, 2013.

Kallis, G.: Droughts, Annu. Rev. Env. Resour., 33, 85-118, 2008.

Kampragou, E., Apostolaki, S., Manoli, E., Frobrich, J., and Assimacopoulos, D.: Towards the harmonization of water-related policies for managing drought risks across the EU, Environ. Sci. Policy, 14, 815-824, 2011.

Karrer, S. L.: Swiss farmers' perception of and response to climate change, Ph.D. thesis, ETH No. 20410, Federal Technical University, Switzerland, 2012.

Keskitalo, E. C. H., Dannevig, H., Hovelsrud, G. K., West, J. J., and Swartling, A. G.: Adaptive capacity determinants in developed states: Examples from the Nordic countries and Russia, Reg. Environ. Change, 3, 579-592, 2011.

Kruse, S., Seidl, I., and Stähli, M.: Informationsbedarf für die Früherkennung von Trockenheit in der Schweiz. Die Sicht potentiell betroffener Nutzergruppen, Wasser Energie Luft, 102, 301304, 2010 (in German).

Kuhlicke, C., Steinfuhrer, A., Begg, C., Bianchizza, C., Bründl, M., Buchecker, M., De Marchi, B., Tarditti, M. D., Hoppner, C., Komac, B., Lemkow, L., Luther, J., McCarthy, S., Pellizzoni, L., Renn, O., Scolobig, A., Supramaniam, M., Tapsell, S., Wachinger, G., Walker, G., Whittle, R., Zorn, M., and Faulkner, H.: Perspectives on social capacity building for natural hazards: outlining an emerging field of research and practice in Europe, Environ. Sci. Policy, 14, 804-814, 2011.

Mayring, P. (Eds.): Qualitative Inhaltsanalyse - Grundlagen und Techniken, Beltz, Weinheim und Basel, Germany, 2010 (in German).

Ministry of Infrastructure and the Environment: Droogteberichten (Drought report), available at: http://www.rws. $\mathrm{nl} /$ water/waterdata_waterberichtgeving/waterberichten/ droogteberichten/, last access: 8 December 2013, 2012 (in Dutch).

Mishra, A. K. and Singh, V. P.: A review of drought concepts, J. Hydrol., 391, 204-216, 2010.

Moretti, M. and Conedera, M.: Waldbrände im Kreuzfeuer [Forest Fire in the Cross Fire], GAIA, 12, 257-279, 2003 (in German).

Murendo, C., Keil, A., and Zeller, M.: Drought impacts and related risk management by smallholder farmers in developing countries: Evidence from Awash river basin, Ethiopia, Risk Management, 13, 247-263, 2011.

Nelson, R., Howden, M., and Smith, M. S.: Using adaptive governance to rethink the way science supports Australian drought policy, Environ. Sci. Policy, 11, 588-601, 2008.

Pezzatti, G. B., Zumbrunnen, T., Bürgi, M., Ambrosetti, P., and Conedera, M.: Fire Regime Shifts as a Consequence of Fire Policy and Socio-Economic Development: An Analysis Based on the Change Point Approach, Forest Policy Econ., 29, 7-18, 2013.

Pfister, C. and Rutishauser, M.: Dürresommer im Schweizer Mittelland seit 1525, Workshopbericht "Trockenheit in der Schweiz", Organe Consultatif sur les Changements Climatiques (OcCC), available at: http://www.occc.ch/reports_e.html, last access: 8 December 2013, 2000 (in German).

Preston, B. L., Yuen, E. J., and Westaway, R. M.: Putting vulnerability to climate change on the map: A review of approaches, benefits, and risks, Sustain. Sci., 6, 177-202, 2011.

ProClim: Hitzesommer 2003, Synthesebericht, Bern, Switzerland, 2005 (in German).

Rebetez, M.: Twentieth century trends in droughts in southern Switzerland, Geophys. Res. Lett., 26, 755-758, 1999.

Reinhard, M., Rebetez, M., and Schlaepfer, R.: Recent climate change: Rethinking drought in the context of forest fire research in Ticino, south of Switzerland, Theor. Appl. Climatol., 82, 17$25,2005$.

Rodewald, R. and Knoepfel, P.: Les canaux d'irrigation. Un modèle de gestion durable de l'eau, in: Les bisses économie, société, patrimoine. Actes du Colloque international, SHVR Société d'Histoire du Valais Romand (Eds.), 131-145, 2011 (in French).

Rossi, G.: Drought Mitigation Measures. A Comprehensive Framework, in: Drought and Drought Mitigation in Europe, edited by: Vogt, J. V. and Somma, F., Kluwer Academic Publishers, Dordrecht, The Netherlands, 233-246, 2000.

Schneider, F. and Homewood, C.: Exploring water governance arrangements in the Swiss Alps from a perspective of adaptive capacity, Mt. Res. Dev., 3, 225-233, doi:10.1659/MRDJOURNAL-D-13-00004.1, 2013.

Seneviratne, S., Orth, R., Jörg-Hess, S., Kruse, S., Seibert, J., Seidl, I., Stahl, K., Stähli, M., Staudinger, M., Weiler, M., and Zappa, M.: Drought-Ch: Trockenheit in der Schweiz. Ergebnisse eines NFP61 Projekts. Aqua \& Gas, 9, 38-47, 2013 (in German). 
Smit, B. and Pilifosova, O.: Adaptation to Climate Change in the Context of Sustainable Development and Equity, in: Climate Change 2001: Impacts, Adaptation, and Vulnerability, Contribution of Working Group II to the Third Assessment Report of the Intergovernmental Panel on Climate Change, edited by: McCarthy, J. J., Canziani, O. F., Leary, N. A., Dokken, D. J., and White, K. S., Cambridge University Press, Cambridge, 877-912, 2001.

Smit, B. and Wandel, J.: Adaptation, adaptive capacity and vulnerability, Global Environ. Chang., 16, 282-292, 2006.

Tate, E. L. and Gustard, A.: Drought Definition. A Hydrological Perspective, in: Drought and Drought Mitigation in Europe, edited by: Vogt, J. V., and Somma, F., Kluwer Academic Publishers, Dordrecht, The Netherlands, 23-48, 2000.

UN-ISDR: Drought Risk Reduction, Framework and Practices: Contributing to the Implementation of the Hyogo Framework of Action, UN-ISDR, Geneva, Switzerland, 2009.

Van Lanen, H. A. J. and Peters, E.: Definition, Effects and Assessment of Groundwater Droughts, in: Drought and Drought Mitigation in Europe, edited by: Vogt, J. V. and Somma, F., Kluwer Academic Publishers, Dordrecht, The Netherlands, 49-62, 2000.

Vogt, J. V. and Somma, F. (Eds.): Drought and Drought Mitigation in Europe, Kluwer Academic Publishers. Dordrecht, The Netherlands, 2000.
Yohe, G. and Tol, R. S. J.: Indicators for social and economic coping capacity - moving toward a working definition of adaptive capacity, Global Environ. Chang., 12, 25-40, 2002.

Vicente-Serrano, S. M., Begueria, S., Gimeno, L., Eklundh, L., Giuliani, G., Weston, D., El Kenawy, A., Lopez-Moreno, J. I., Nieto, R., Ayenew, T., Konte, D., Ardo, J., and Pegram, G. G. S.: Challenges for drought mitigation in Africa: The potential use of geospatial data and drought information systems, Appl. Geogr., 34, 471-486, 2012.

Wilhite, D. A., Hayes, M. J., Knutson, C., and Smith, K. H.: Planning for drought: Moving from crisis to risk management, J. Am. Water Resources As., 36, 697-710, 2000.

Willi, H. P.: Warnungen und ihre Rolle in der BAFU-Strategie zur Gefahrenprävention, in: Warnung bei aussergewöhnlichen Naturereignissen, editeg by: Hegg, C. and Rhyner, J., Forum für Wissen, Birmensdorf: Eidg. Forschunsganstalt WSL, 7-9, 2007 (in German).

Wittrock, V., Kulshreshtha, S. N., and Wheaton, E.: Canadian prairie rural communities: Their vulnerabilities and adaptive capacities to drought, Mitigation and Adaptation Strategies for Global Change, 16, 267-290, 2011. 